Abstracta Iranica Abstracta Iranica

Revue bibliographique pour le domaine irano-aryen

Volume 34-35-36 | 2017

Comptes rendus des publications de 2011-2013

\title{
Leonardo Gregoratti. The importance of the Mint of Seleucia on the Tigris for Arsacid History: Artabanus and the Greek Parthian Cities
}

Fabrizio Sinisi

\section{(2) OpenEdition \\ Journals}

Electronic version

URL: http://journals.openedition.org/abstractairanica/42342

DOI: 10.4000/abstractairanica.42342

ISSN: 1961-960X

Publisher:

CNRS (UMR 7528 Mondes iraniens et indiens), Éditions de l'IFRI

\section{Electronic reference}

Fabrizio Sinisi, «Leonardo Gregoratti. The importance of the Mint of Seleucia on the Tigris for Arsacid History: Artabanus and the Greek Parthian Cities », Abstracta Iranica [Online], Volume 34-35-36 | 2017, document 54, Online since 30 July 2017, connection on 26 September 2020. URL : http:// journals.openedition.org/abstractairanica/42342 ; DOI : https://doi.org/10.4000/abstractairanica. 42342

This text was automatically generated on 26 September 2020 .

Tous droits réservés 


\title{
Leonardo Gregoratti. The importance of the Mint of Seleucia on the Tigris for Arsacid History: Artabanus and the Greek Parthian Cities
}

\author{
Fabrizio Sinisi
}

\section{REFERENCES}

Leonardo Gregoratti. « The importance of the Mint of Seleucia on the Tigris for Arsacid History: Artabanus and the Greek Parthian Cities ». Mesopotamia, 47, 2012, p. 129-136.

1 The policy of Artabanus II (12-38/40 CE) towards the Greek cities is analyzed, detecting a gradual penetration of the royal power in the municipal institutions as opposed to the idea of a direct conflict. This took place through various means, as shown by the famous letter to the city of Susa of $21 / 22 \mathrm{CE}$, aiming at a general consolidation of Arsacid control on all the entities which coexisted within the empire. A special focus is devoted to the civic coinage of Seleucia struck in the years of the reign of Artabanus. The appearance on such coins of the personification of the city Boule first and then of explicitly royal images attests to the success of Artabanus' strategy to support the oligarchic faction in the political life of Seleucia in order to strengthen the position of the monarchy within the city. 


\section{AUTHORS}

FABRIZIO SINISI

Österreichische Akademie der Wissenschaften 